\title{
The Analysis of the Chlorogenic Acid in the Ethanol Fraction of Robusta Coffee Beans and Its Effect on Glucose Levels in Wistar Rats
}

\author{
Rusman Hasanuddin ${ }^{1}$, Jasmiadi $^{2}$, \& Nurliana Abdillah ${ }^{3^{*}}$ \\ Faculty of Mathematics and Natural Sciences, Department of Pharmacy, Makassar Islamic \\ University, Indonesia \\ *corresponding author, email: rusman.dty@uim-makassar.ac.id
}

Received: 19/08/2021; published:15/09/2021

\begin{abstract}
Background: The metabolic disorder caused by high blood glucose levels and pancreatic betacell damage is known as diabetes mellitus. Indonesia itself is the 7th country in the world with the number of people with diabetes mellitus. Indonesia occupies rank 7 in the world with the number of people with diabetes mellitus. Apart from that, robusta coffee (Coffea canephora $L$ ) is one of the most popular drinks globally, including Indonesia. Chlorogenic acid in coffee beans effectively reduces cell damage due to free radicals, including minimizing excessive glucose release from the liver into the blood. Objective: This study aimed to analyze the effects of chlorogenic acid in the ethanolic fraction of robusta coffee (Coffea canephora $L$ ) beans on blood glucose levels in Wistar rats. Method: The researchers applied an experimental study with a randomized pretest-posttest control group design. The beans of robusta coffee were extracted using the Maceration method and then fractionated using a hexane and ethyl acetate solvent. The concentration of the obtained remaining fraction was measured using a spectrophotometer. Furthermore, hyperglycemia testing included 30 Wistar rats induced with $20 \%$ glucose for $3-4$ weeks. They were then given the ethanol fraction of robusta coffee with a dose of $400 \mathrm{mg} / \mathrm{kg}$ BW and $500 \mathrm{mg} / \mathrm{kg} \mathrm{BW}$. Meanwhile, metformin served as a positive control, and $\mathrm{NaCMC}$ served as a negative control. Results: The chlorogenic acid analysis in the ethanol fraction of robusta coffee on a spectrophotometer with a concentration of $37 \%$ indicated a decrease of $16.66 \%$ on the negative control and $48.06 \%$ on the positive control. Meanwhile, the ethanol fraction of each control was $51.53 \%$ and $52.16 \%$, respectively. Conclusion: The ethanol fraction of the robusta coffee significantly affects the decrease in blood glucose levels in Wistar rats.
\end{abstract}

Keywords: Coffea canephora L., chlorogenic acid, glucose

This is an open-access article under the CC-BY-SA license.

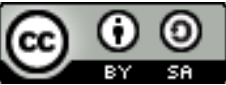

\section{Introduction}

The International Diabetes Federation reported that around 382 million people suffered from diabetes mellitus in 2013. Furthermore, it is estimated that there will be 592 million sufferers in 2035 or an increase of $55 \%$. Indonesia ranks seventh highest diabetes mellitus sufferers globally, reaching 8.5 million sufferers in $2013[1,2]$.

Diabetes mellitus is a group of metabolism disorders of fat, carbohydrates, and protein because of the damage in insulin secretion, insulin action (sensitivity), or both $[3,4]$. The increase in diabetes mellitus sufferers in developing countries is due to changes in dietary habits from healthy, high-fiber, low-fat, low-calorie traditional foods to the increased consumption of calorie-containing foods, such as simple carbohydrates, fat, red meat, and low fiber food [5-7].

Robusta coffee bean powder contains chlorogenic acid, a phenolic group compound [810]. Furthermore, robusta coffee beans contain the most chlorogenic acid compared to other coffee beans [11-13]. According to Dr. J. Murdoch Ritchie in the book 'The Pharmacological 
Basis of Therapeutic,' the caffeine in $1-2$ cups of coffee can increase heart rate, increase thought and inspiration speed, reduce drowsiness and fatigue, increased sensory stimuli and motor reactions, generate vasodilation, and encourage the flow of fluid secretions and solid secretions from the body so that the body feels fresher $(11,14-16)$.

Chlorogenic acid (CGA) maximizes the potential of insulin action, similar to the therapeutic action of metformin. Chlorogenic acid at a dose of $5 \mathrm{mg} / \mathrm{kg}$ BW may provide antidiabetic potential in rats $[17,18]$. Based on the elaboration above, it is necessary to carry out a study on the effect of the provision of the remaining fraction of Robusta coffee (Coffea canephora $L$.) beans to reduce blood glucose levels in Wistar rats (Rattus norvegicus) [13,1921].

\section{Method}

This study was experimental research with a randomized pretest-posttest control group design. Robusta coffee (Coffea canephora L.) beans were taken from Rante Kalua Village, Mangkendek, Tana Toraja, South Sulawesi. This study was conducted from February to April 2021. After providing the negative control, the positive control, and the remaining fraction of robusta coffee beans, the research data were collected and analyzed by the ANOVA using a completely randomized design and further tested using Duncan's test.

The tools used in this study were Erlenmeyer flask, beaker (Phirex), graduated cylinder, glucometer (Elvasense), hot plate, mouse cannula, scale pipette, centrifuge, $5 \mathrm{~mL}$ syringe, and stirrer. Meanwhile, the materials used in this study were robusta coffee (Coffea canephora L.) beans, a solvent for extraction and partitioning. Furthermore, the chemicals used were distilled water (Aquadest), chlorogenic acid p.a (Sciecewerke), 70\% ethanol (One med), ethyl acetate (Merck), glucose (Merck), metformin (Sciencewerke), 1\% Na CMC, and n-hexane (C6H14).

Extraction was conducted by the maceration method. $500 \mathrm{~g}$ coffee beans were macerated with a mixture of $1050 \mathrm{~mL}$ of Aquadest and $450 \mathrm{~mL}$ of $70 \%$ ethanol (with a ratio of 7:3) for $3 \times$ 24 hours. After that, it was filtered until the filtrate was obtained. The filtrate was evaporated using a rotary evaporator to produce a thick extract. Furthermore, it was followed by carrying out the re-maceration with the same solvent. The concentrated extract was dissolved in 100 $\mathrm{mL}$ of ethanol and partitioned using $3 \times 70 \mathrm{~mL}$ of $\mathrm{n}$-hexane. The $\mathrm{n}$-hexane fraction was then concentrated. The ethanol fraction was further partitioned using $3 \times 70 \mathrm{~mL}$ of ethyl acetate as a solvent. The ethyl acetate fraction and the remaining fraction were then concentrated.

There were 20 rats used in this study. They were divided into five groups, consisting of 4 rats (taken randomly) for each. The rats underwent a fast for 8 hours before the treatment was given. After that, their initial fasting blood glucose levels were measured using a glucometer. Furthermore, they were induced with $20 \%$ glucose orally. Their blood was drawn again through the lateral vein. Their blood glucose levels were measured again after the induction process. Group I was given 1\% Na-CMC solution as a negative control. Group II was given metformin as a positive control. $400 \mathrm{mg} / \mathrm{kg}$ BW was given to group III the remaining fraction of robusta coffee beans. Group IV was given the remaining fraction of robusta coffee beans by $500 \mathrm{mg} / \mathrm{kg}$ BW. Group V was given chlorogenic acid by $5 \mathrm{mg} / \mathrm{kg} \mathrm{BW}$. Measurement of blood glucose levels was carried out on days 4 and 7 using a glucometer.

The blood draw was conducted by wiping the rats' tails with a cotton swab which was first given $70 \%$ alcohol, and then the rats' tails were cut using scissors that had been cleaned with $70 \%$ alcohol. After that, the tail was held tightly until the blood came out at the tip of the lateral vein. The blood that came out was then dripped onto the strip. Furthermore, the tip of the lateral vein was rubbed with a cotton swab given $70 \%$ alcohol so that blood from the lateral vein did not come out.

\section{Results and Discussion}

\subsection{Results}

3.1.1. Subsubsection

Data on the average decrease in blood glucose levels after induction and after the provision of the ethanol fraction of robusta coffee bean for group I $(1 \% \mathrm{NaCMC}$ (negative control)), group II (metformin (positive control)), group III (the ethanol fraction of Robusta coffee bean by $400 \mathrm{mg} / \mathrm{kg} \mathrm{BW}$ ), group IV (the ethanol fraction of Robusta coffee bean by 
$500 \mathrm{mg} / \mathrm{kg} \mathrm{BW}$ ), and group V (chlorogenic acid by $5 \mathrm{mg} / \mathrm{kg} \mathrm{BW}$ ) are presented in the following table.

Table 1. Data of the Average Decrease in Blood Glucose Levels

\begin{tabular}{|c|c|c|c|c|c|c|}
\hline & Rats & $\begin{array}{l}\text { Initial } \\
\text { blood } \\
\text { glucose } \\
\text { level (n) }\end{array}$ & $\begin{array}{l}\text { Blood glucose } \\
\text { levels after } \\
\text { induction (n) }\end{array}$ & $\begin{array}{c}\text { Blooc } \\
\text { leve } \\
\text { tre } \\
\text { prov } \\
4\end{array}$ & $\begin{array}{l}\text { cose } \\
\text { fter } \\
\text { ent } \\
\text { (n) } \\
7\end{array}$ & $\begin{array}{c}\text { Decreased } \\
(\%)\end{array}$ \\
\hline & 1 & 161 & 162 & 96 & 125 & 22.84 \\
\hline Group I & 2 & 106 & 138 & 75 & 102 & 26.09 \\
\hline & & 133.5 & 150 & 85.5 & 113.5 & 24.46 \\
\hline & 1 & 107 & 147 & 131 & 88 & 40.14 \\
\hline Group II & 2 & 84 & 184 & 104 & 81 & 55.98 \\
\hline & & 95.5 & 165.5 & 117.5 & 84.5 & 48.06 \\
\hline & 1 & 77 & 186 & 160 & 74 & 60.22 \\
\hline & 2 & 87 & 138 & 119 & 100 & 27.54 \\
\hline Group III & 3 & 86 & 253 & 110 & 86 & 66.01 \\
\hline & 4 & 71 & 149 & 123 & 71 & 52.35 \\
\hline & & 80.25 & 181.5 & 128 & 82.75 & 51.53 \\
\hline & 1 & 75 & 166 & 156 & 97 & 41.57 \\
\hline & 2 & 91 & 185 & 170 & 93 & 49.73 \\
\hline Group IV & 3 & 69 & 219 & 195 & 85 & 61.19 \\
\hline & 4 & 73 & 203 & 157 & 89 & 56.16 \\
\hline & & 77 & 193.25 & 169.5 & 91 & 52.16 \\
\hline & 1 & 104 & 194 & 155 & 101 & 47.94 \\
\hline $\mathrm{Gr}$ & 2 & 97 & 187 & 99 & 80 & 57.22 \\
\hline & & 100.5 & 190.5 & 127 & 90.5 & 52.58 \\
\hline
\end{tabular}

3.1.2. Statistical Analysis

Because Fcount is > Ftable, $\mathrm{H} 0$ was rejected. Therefore, $\mathrm{H} 1$ was accepted. In other words, the ethanol fraction of robusta coffee beans affect the blood glucose levels of Wistar rats.

Table 2. Results of Analysis of Variance (ANOVA)

\begin{tabular}{|c|c|c|c|c|c|c|c|}
\hline \multirow{2}{*}{$\begin{array}{l}\text { Source of } \\
\text { Uniformity }\end{array}$} & \multirow{2}{*}{ DF } & \multirow{2}{*}{ Squared } & \multirow{2}{*}{$\begin{array}{l}\text { Middle } \\
\text { Squared }\end{array}$} & \multirow{2}{*}{$\mathbf{F}_{\text {count }}$} & \multicolumn{2}{|c|}{$F_{\text {table }}$} & \multirow{2}{*}{ Note } \\
\hline & & & & & $5 \%$ & $1 \%$ & \\
\hline Correction Factor & 1 & 11696.23 & 11696.23 & & & & \\
\hline Treatment & 4 & 21866.93 & 5466.73 & $17,37^{*}$ & 3.06 & 4.89 & Uniform \\
\hline Error & 15 & 4719.62 & 314.64 & & & & \\
\hline Total & 20 & 38282.78 & & & & & \\
\hline
\end{tabular}

3.1.3 Further Analysis Using Duncan's New Multiple Range (DNMR) Test

$\mathrm{P} 1$ was the group given $1 \% \mathrm{NaCMC}$; P2 was the group given metformin; P3 was the group given the ethanol fraction of robusta coffee bean by $400 \mathrm{mg} / \mathrm{kg} \mathrm{BW} ; \mathrm{P} 4$ was the group given the ethanol fraction of robusta coffee bean by $500 \mathrm{mg} / \mathrm{kg} \mathrm{BW}$; P5 was the group given chlorogenic acid by $5 \mathrm{mg} / \mathrm{kg}$ BW. The difference of $>1 \%$ and $>5 \%$ indicated high significance; the difference of $<1 \%$ and $<5 \%$ indicated no significance; the difference of $<1 \%$ and $>5 \%$ indicated the presence of significance. 
Table 3. Analysis of treatments on Wistar rats in the confidence levels of $1 \%$ and $5 \%$

\begin{tabular}{ccccc}
\hline \multirow{2}{*}{ Treatments } & \multirow{2}{*}{ Difference } & \multicolumn{2}{c}{ Significance } & \multirow{2}{*}{ Note } \\
\cline { 2 - 4 } & & $5 \%$ & $1 \%$ & \\
\hline P1-P2 & 8.07 & 26.73130856 & 36.95732 & Not significant \\
P1-P3 & 34.86 & 28.02618947 & 38.54488 & Significant \\
P1-P4 & 35.5 & 28.82440372 & 39.58256 & Significant \\
P1- P5 & 29.44 & 29.37428 & 40.32755807 & Significant \\
P2 - P3 & 26.79 & 26.73130856 & 36.95732 & Significant \\
P2 - P4 & 27.43 & 28.02618947 & 38.54488 & Not significant \\
P2 - P5 & 21.37 & 28.82440372 & 39.58256 & Not significant \\
P3-P4 & 0.64 & 29.37428 & 40.32755807 & Not significant \\
P3-P5 & 5.42 & 26.73130856 & 36.95732 & Not significant \\
P4-P5 & 6.06 & 28.02618947 & 38.54488 & Not significant \\
\hline
\end{tabular}

\subsection{Discussion}

This study was conducted to determine the effect of the remaining ethanol fraction of Robusta coffee (Coffea canephora L.) beans by employing 20 rats divided into five groups. Blood glucose checks were carried out four times using a glucometer. The principle of the test with this instrument is based on a small electric current generated by the reaction of blood sugar with a test strip reagent. The glucometer calculates and converts this current into a numerical value for blood sugar and then displays the results on the screen.

Based on Table 1, it was found out that after the provision of $20 \%$ glucose, blood glucose levels in the rats' bodies increased above normal limits compared to their initial blood glucose. There was an increase in blood glucose in each treatment group because glucose given orally would be absorbed from the small intestine into the blood. However, some rats in groups 1, 2, and 5 ( 2 cases each group) did not experience an increase in blood glucose after glucose induction, so that the rats were eliminated. This can be caused by several factors or conditions, such as stress, increased activity, or error during glucose induction $[22,23]$.

Stress conditions in rats may cause disturbances in controlling blood sugar levels by hormones so that the body will produce the epinephrine hormones and cortisol, which cause blood sugar levels to increase automatically $[24,25]$. Another factor is the increased activity. Physical activity can control blood sugar by converting glucose into energy during physical activity. Physical activity causes insulin to increase so that blood sugar levels will decrease. In less mobile rats, food substances that entered their bodies were not burned but stored as fat and sugar [26-28]. According to Malole (1989), normal blood glucose levels in rats were $50-135 \mathrm{mg} / \mathrm{dL}$.

The provision of $\mathrm{NaCMC}$ as a negative control resulted in the lowest percentage reduction in blood glucose levels, namely $24.46 \%$. It was because they were only given $\mathrm{NaCMC}$, which had no activity in reducing blood glucose levels. Meanwhile, the treatment with metformin as a positive control group showed a decrease in rats' blood glucose levels by $48.06 \%$. This was because metformin is one of the biguanide antidiabetic oral drugs that works by increasing the body's sensitivity to the insulin produced by the pancreas, decreasing hepatic glucose production through activation of the AMP-activated protein kinase enzyme, and increasing stimulation of glucose uptake by skeletal muscle and fat tissue [12-14].

The provision of the remaining fraction of robusta coffee beans resulted in a decrease in blood glucose levels. The decrease was $51.53 \%$ at a dose of $400 \mathrm{mg} / \mathrm{kg} \mathrm{BW}$ and $52.16 \%$ at a dose of $500 \mathrm{mg} / \mathrm{kg} \mathrm{BW}$. Meanwhile, the provision of chlorogenic acid with a dose of 5 $\mathrm{mg} / \mathrm{kg} \mathrm{BW}$ decreased blood glucose levels by $52.58 \%$. The decrease in blood glucose levels due to the provision of the remaining fraction of robusta coffee beans and chlorogenic acid was higher when compared to that of metformin (positive control). This was because coffee contains chlorogenic acid compounds, which can reduce intracellular hyperglycemia by regulating fat and glucose metabolism through AMPK activation [29]. Chlorogenic acid can inhibit G6Pase expression and increase fasting glucose, glucose tolerance, and insulin sensitivity [30]. 
Data from the results of statistical analysis using the ANOVA with a completely randomized design (CRD) shown in Table 7 indicated that the $F$ count was $<F$ table with a confidence level of $5 \%$ and $1 \%$, meaning that the provision of the remaining fraction of robusta coffee beans has an insignificant effect on blood glucose levels in Wistar rats. The statistical analysis results also indicated a uniformity coefficient of $64.6 \%$, which is greater than $10 \%$. Therefore, the test was followed by Duncan's test. The results of Duncan's test are presented in Table 3.

Based on the difference in $1 \%$ and $5 \%$ confidence levels, group I (negative control) showed a significant difference with those given metformin (positive control). Those given the remaining fraction of robusta coffee beans with doses of $400 \mathrm{mg} / \mathrm{kg} \mathrm{BW}$ and $500 \mathrm{mg} / \mathrm{kg}$ $\mathrm{BW}$, and those given chlorogenic acid with a dose of $5 \mathrm{mg} / \mathrm{kg} \mathrm{BW}$, in which the effect of the decrease in the percentage of blood glucose in each dose was more significant than the negative control, indicating that the fraction was able to reduce blood glucose levels. Group Il (positive control) showed insignificant differences with the groups given the remaining fraction of Robusta coffee beans and chlorogenic acid. This means that the remaining fraction of robusta coffee beans and chlorogenic acid has the same effect as metformin circulating in the market.

\section{Conclusion}

Based upon the results and discussions aforementioned can be concluded that the ethanol fraction of Robusta coffee beans (Coffea canephora L.) has effects on decreasing blood glucose in Wistar rats. Furthermore, the group given the ethanol fraction of robusta coffee beans at a $400 \mathrm{mg} / \mathrm{kg}$ BW dose showed a significant difference with that given metformin as the positive control.

\section{References}

1. Atlas IDFD. International Diabetes Federation. Vol. 266, The Lancet. 2019. 134-137 p. DOI: https://doi.org/10.1016/s0140-6736(55)92135-8

2. Alan R. Saltiel JEP. Anti-oxidant and Anti-Diabetic Activities of Ethanolic Extract of Primula Denticulata Flowers. Indones J Pharm. 2016;27(2):74-9. DOI: https://doi.org/10.14499/indonesianjpharm27iss2pp74

3. Okada J, Osaki A, Shimoda Y, Yamada E, Saito T, Ozawa A, et al. Differences in the Effects of Kenyan, Tanzanian, and Ethiopian Coffee Intake on Interstitial Glucose Levels Measured by FreeStyle Libre: A Pilot Case Study. Curr Ther Res Clin Exp. 2020;93:100606. DOI: https://doi.org/10.1016/j.curtheres.2020.100606

4. Budiyani L, Purnamasari D, Simadibrata M, Abdullah M. Insulin Resistance in Gastroesophageal Reflux Disease. Acta Med Indones. 2018;50(4):336-42. DOI: https://doi.org/10.15605/jafes.03.02.07

5. Mishra V, Jyoti J, Kaur M, Mittal A. Sweet Future of Stevia : A Magical Sweetener Sweet Future of Stevia: A Magical Sweetener. 2019;(February 2018). DOI: https://doi.org/10.22159/ajpcr.2018.v11i2.20295

6. Sari DRAP, Ahmad FF, Djabir YY, Yulianty R. Breadfruit Leaves Extract (Artocarpus Altilis) Effect on Pancreatic Damage in Diabetic Type II Animal Model Induced by AlloxanNicotinamide. Med Clin Pract. 2020;3:100099. DOI: https://doi.org/10.1016/j.mcpsp.2020.100099

7. Refardt J, Winzeler B, Christ-Crain M. Diabetes Insipidus: An Update. Endocrinol Metab Clin North Am. 2020;49(3):517-31. DOI: https://doi.org/10.1016/j.ecl.2020.05.012

8. Curti V, Verri M, Baldi A, Dacrema M, Masiello I, Dossena M, et al. In vivo Modulatory Effect of Coffee (Coffea canephora var. Robusta) on the Expression Levels of Murine microRNA-124-3p Associated with Antioxidant Defenses. eFood. 2019; DOI: https://doi.org/10.2991/efood.k.190802.001

9. Santos RMM, Lima DRA. Coffee Consumption, Obesity and Type 2 Diabetes: A MiniReview. Eur J Nutr. 2016 Jun;55(4):1345-58. DOI: https://doi.org/10.1007/s00394-0161206-0

10. Ghaedi N, Pouraboli I, Askari N. Antidiabetic Properties of Hydroalcoholic Leaf and Stem Extract of Levisticum officinale: An Implication for a-amylase Inhibitory Activity of Extract Ingredients through Molecular Docking. Iran J Pharm Res IJPR. 2020;19(1):231-50. DOI: 
https://doi.org/10.31838/ijpr/2020.12.03.002

11. Morvaridi M, Rayyani E, Jaafari M, Khiabani A, Rahimlou M. The Effect of Green Coffee Extract Supplementation on Cardio Metabolic Risk Factors: A Systematic Review and Meta-Analysis of Randomized Controlled Trials. J Diabetes Metab Disord. 2020 Jun;19(1):645-60. DOI: https://doi.org/10.1007/s40200-020-00536-x

12. Wang Y, Peng S, Mei Z, Jin C, Kang J, Xiang M, et al. Chlorogenic Acid Inhibits Forming of Diabetes Mellitus in Rats Induced by High-Fat High-Sucrose and Streptozotocin. Pak J Pharm Sci. 2020 May;33(3):1063-72. DOI: https://doi.org/10.3389/fimmu.2020.01125

13. Guo CC, Zhang XY, Wang YX, Xie L, Chang CQ. [Effects of Chlorogenic Acid on Glucose Tolerance and Its Curve Characteristics in High-Fat Diet-Induced Obesity Rats]. Beijing Da Xue Xue Bao. 2020 Apr;52(2):269-74. DOI: https://doi.org/10.1093/cdn/nzaa045_010

14. Zuñiga LY, Aceves-De La Mora MCA De, González-Ortiz M, Ramos-Núñez JL, MartínezAbundis E. Effect of Chlorogenic Acid Administration on Glycemic Control, Insulin Secretion, and Insulin Sensitivity in Patients with Impaired Glucose Tolerance. J Med Food. 2018;21(5):469-73. DOI: https://doi.org/10.1089/jmf.2017.0110

15. Naveed M, Hejazi V, Abbas M, Kamboh AA, Khan GJ, Shumzaid M, et al. Chlorogenic acid (CGA): A Pharmacological Review and Call For Further Research. Biomed Pharmacother. 2018;97(October 2017):67-74. DOI: http://dx.doi.org/10.1016/j.biopha.2017.10.064

16. Miao M, Xiang L. Pharmacological Action and Potential Targets of Chlorogenic Acid. 1st ed. Vol. 87, Advances in Pharmacology. Elsevier Inc.; 2020. 71-88 p. DOI: http://dx.doi.org/10.1016/bs.apha.2019.12.002

17. Barre DE, Mizier-Barre KA. The Polypharmacy Reduction Potential of Cinnamic Acids and Some Related Compounds in Pre- and Post-Onset Management of Type 2 Diabetes Mellitus. Endocr Regul. 2020 Apr;54(2):137-55. DOI: https://doi.org/10.2478/enr-20200017

18. Williamson G. Protection Against Developing Type 2 Diabetes by Coffee Consumption: Assessment of the Role of Chlorogenic Acid and Metabolites on Glycaemic Responses. Food Funct. 2020 Jun;11(6):4826-33. DOI: https://doi.org/10.1039/d0fo01168a

19. Asbaghi O, Sadeghian M, Nasiri M, Khodadost M, Shokri A, Panahande B, et al. The Effects of Green Coffee Extract Supplementation on Glycemic Indices and Lipid Profile in Adults: A Systematic Review and Dose-Response Meta-Analysis of Clinical Trials. Nutr J. 2020 Jul;19(1):71. DOI: https://doi.org/10.1186/s12937-020-00587-z

20. Santana-Gálvez J, Cisneros-Zevallos L, Jacobo-Velázquez DA. Chlorogenic Acid: Recent Advances on Its Dual Role as a Food Additive and a Nutraceutical Against Metabolic Syndrome. Molecules. 2017;22(3):7-9. DOI: https://doi.org/10.3390/molecules22030358

21. Kocak MZ, Aktas G, Erkus E, Yis OM, Duman TT, Atak BM, et al. Neuregulin-4 is Associated with Plasma Glucose and Increased Risk of Type 2 Diabetes Mellitus. Swiss Med Wkly. 2019;149(October):w20139. DOI: https://doi.org/10.4414/smw.2019.20139

22. Olivares AM, Althoff K, Chen GF, Wu S, Morrisson MA, DeAngelis MM, et al. Animal Models of Diabetic Retinopathy. Curr Diab Rep. 2017;17(10). DOI: https://doi.org/10.1007/s11892-017-0913-0

23. Riehle C, Bauersachs J. Of Mice and Men: Models and Mechanisms of Diabetic Cardiomyopathy. Basic Res Cardiol. 2019;114(1):1-22. DOI: https://doi.org/10.1007/s00395-018-0711-0

24. Azushima K, Gurley SB, Coffman TM. Modelling Diabetic Nephropathy in Mice. Nat Rev Nephrol. 2017;14(1):48-56. DOI: http://dx.doi.org/10.1038/nrneph.2017.142

25. Xu L, Li Y, Dai Y, Peng J. Natural Products for the Treatment of Type 2 Diabetes Mellitus: Pharmacology and Mechanisms. Pharmacol Res. 2018;130:451-65. DOI: http://dx.doi.org/10.1016/j.phrs.2018.01.015

26. Zilliox LA, Russell JW. Physical Activity and Dietary Interventions in Diabetic Neuropathy: A Systematic Review. Clin Auton Res. 2019;29(4):443-55. DOI: https://doi.org/10.1007/s10286-019-00607-x

27. Wang D, Hou J, Wan J, Yang Y, Liu S, Li X, et al. Dietary Chlorogenic Acid Ameliorates Oxidative Stress and Improves Endothelial Function in Diabetic Mice Via Nrf2 Activation. $J$ Int Med Res. 2021;49(1). DOI: https://doi.org/10.1177/0300060520985363

28. Yin X-L, Xu B-Q, Zhang Y-Q. Gynura Divaricata Rich In 3, 5-/4, 5-Dicaffeoylquinic Acid

The Analysis of the Chlorogenic Acid in the Ethanol Fraction of ....... (Rusman Hasanuddin) 
and Chlorogenic Acid Reduces Islet Cell Apoptosis and Improves Pancreatic Function in Type 2 Diabetic Mice. Nutr Metab (Lond). 2018;15:73. DOI: https://doi.org/10.1186/s12986-018-0310-y

29. Reis CEG, Dórea JG, da Costa THM. Effects of Coffee Consumption on Glucose Metabolism: A Systematic Review of Clinical Trials. Vol. 9, Journal of Traditional and Complementary Medicine. 2019. p. 184-91. DOI: https://doi.org/10.1016/j.jtcme.2018.01.001

30. Yan Y, Zhou X, Guo K, Zhou F, Yang H. Review Article Use of Chlorogenic Acid against Diabetes Mellitus and Its Complications. 2020;2020. DOI: https://doi.org/10.1155/2020/9680508 